\title{
Usefulness of Social Networking Sites towards Malaysian Tertiary Education's Student Life of Learning and Social
}

\author{
Ilangovan Perumal, Azween Abdullah, Muthaloo Subramaniam, Mahadevan Supramaniam \\ Sugumaran Selladurai
}

\begin{abstract}
In this current generation, there is great popularity of student in using internet as well as the web 2.0 for different purposes in their daily life, for instance, the primary uses found are for the email, communication and academic-related work. Nonetheless, according to the past research, there determined there is loose relationship between the technology (such as the Facebook as the Web 2.0 technology)) used by the students for their learning purposes. Also, such studies are usually conducted in the Western countries rather than in the Asian countries such as Malaysia. Thus, the research aim is to determine the usefulness of the social networking sites toward Malaysia tertiary education's student life of social and learning and to investigate whether Facebook could be a preferred SNS choice by the students in aiding their learning and social life. Self-administered questionnaires would be distributed to 200 students who studying at Malaysia tertiary education institution located across Klang Valley. As a result, this study has determined there is positive relationship between the usefulness of the social networking sites toward Malaysia student life of social and learning.
\end{abstract}

Keywords: Web 2.0, Social Networking, Social and Learning

\section{INTRODUCTION}

According to the previous research, the researchers study the way of college students in using internet for different purposes in their daily life (Jones, Johnson-Yale, Millermaier, \& Perez, 2009) In 1996, Wilson (1999) found the primary uses of internet by college students are regarding to email, course-related research and communicating in online groups. Wilson's research shown that, most of the students spent an average of 2.6 hours per week on the internet. Furthermore, after the surveying a huge sample of 143,730 students at 63 US higher education institution, Kvavik and Caruso (2005) reported approximately 99.7 percent of the students used

Revised Manuscript Received on September 22, 2019

* Correspondence Author

Ilangovan Perumal*, Faculty of Business, Accounting and Management, SEGi University, Kota Damansara, Malaysia. Email: ilangovan@segi.edu.my

Azween Abdullah, School of Computing and IT, Faculty of Innovation and Technology, Taylor's University, Subang Jaya, Malaysia. Email: azween.abdullah@taylors.edu.my

Muthaloo Subramaniam, Faculty of Business, Accounting and Management, SEGi University, Kota Damansara, Malaysia. Email: muthaloo@segi.edu.my

Mahadevan Supramaniam, Research and Innovation Management Centre \& Institute of Graduate Studies, SEGi University, Kota Damansara, Malaysia. Email: mahadevans@ segi.edu.my

Sugumaran Selladurai, Faculty of Business, Accounting and Management, SEGi University, Kota Damansara, Malaysia. Email: sugumaran@segi.edu.my technology for email as well as for course related works. Yet, research studies regarding to the usefulness of internet media (such as SNS) on the college student life were highly focused on the developed countries and it is necessary to discuss whether the finding discovered previously could be generalized to the developing country's students such as Malaysian (Zakaria, 2010). As stated by Barnes (2006), social network sites are one of the Web 2.0 tools and also known as SNS, are defined as the web-enabled services which the individuals could create their public or private profile within a bounded system, for instance, the Facebook. Its extensive features such as the personal profile, is enabling the people to interact for maintaining the current personal or professional networks or to create new connections without geographic constraints (Cormode and Krishnamurthy, 2008).

As for the socializing dimension, as stated by Greenhow (2011), internet tool such as social networking sites could stimulate social benefits in both online and offline. Meanwhile, it helps with school-related tasks (Greenhow \& Robelia, 2009a) For example, these including by using online chatting of SNS to mitigate school-related stress and planning study groups (Greenhow, 2011) The question asked is related to whether the students doing something with educational value when using SNS (Greenhow, 2011) According to past study of Greenhow and Robelia (2009a, b), the students from the urban families who living in the upper part of Midwestern part of the USA perceived SNS such as MySpace is providing social support and it is a platform for these students for self-expression and self-presentation. Also, by prolonging the SNS membership, the students believe they could conveniently communicate and understand their friends better through the platform due to the SNS encouraging the norm of openness as well as sharing of self-identity (Greenhow, 2011) Nonetheless, there is lacking of research on the finding about the use of internet tool such as Web 2.0 by students in Malaysia (Zakaria, 2010) Thus, it is important to analyze the way of Malaysia students in using the Web 2.0 (such as SNS) and how do these could support them in both learning and social-networking. Additionally, there is a published report on online usage of Malaysia (comScore, 2009), stating the most-visited website by Malaysian is the social-networking sites and 9.3 millions of Malaysian are spending nearly 14 hours per month. Nonetheless, it was detected as there is loose relationship between the technology used by students and the way they used for learning. This past research stating the well-established tools for learning are the Learning 
Management System, Wikipedia and so on (Zakaria, 2010), and the use of social technologies by students are limited for learning purpose (Kennedy et al, 2007).

\section{LITERATURE REVIEW}

\section{A. The Usefulness of Internet Media in the Life of College/University Students}

According to Jones research (Jones et al, 2009), the students are making use of internet for different purposes in their daily living. These main purposes are the students using internet for course-related work and online communication in group (Wilson, 1999) As Kvavik and Caruso (2005) conducted a survey about the usefulness of internet media for students, they found out 98.4 percent out of 18, 039 respondents originated from 63 US higher education institutions, used internet for course-related writing. Those internet media includes of those from the Web 2.0 tools, they could be used for learning and social purposes, such as the blogs and wikis which maintained in low level of use, as for those well-established, they are the learning management system, Google, and Wikipedia, while the Web 2.0 tools such as the Social Networking Sites are made limited used by the students (Kennedy et al, 2007) As according to Comscore (2009), the top visited website by the Malaysian is the social-networking site, in which 9.3 million of the Malaysian spent 14 hours on it per month. Nevertheless, information reveals a weak relationship between the use of SNS and the way the students used for learning (Zakaria, 2010).

Nonetheless, the studies regarding to the use of internet media (such as SNS) for the benefits of university students' learning and socializing, were usually focused on the developed countries such as USA and UK in enhancing the learning of students in higher education institution (Zakaria, 2010) Yet, as stated by Zakaria (2010), it is necessary to discuss whether the similar result could be generalized to the students of other developing countries such as Malaysia.

\section{B. Social Uses of Internet in Learning \& Networking}

A research survey conducted on the freshmen students from residence of mid-Atlantic "midsized public research university" (Cotton \& Jelenewicz, 2006), has shown 97 percent of all the students, they have spent 28 hours per week for communicative purposes via the use of internet. College students are also detected as the most frequent users of social-networking sites especially the Facebook (Jones et al, 2009) In Malaysia, a newly-published report from comScore (2009), the top visited websites are the social networking sites which additionally there are 9.3 millions of Malaysian (age from 15 and above) are using internet from various location and averagely assess to 1,066 pages of content per month. Even though there are proofs that the technologies have penetrated into the learning area of higher education, but the students deemed not actively involve the use of such technologies for their learning (Zakaria, 2010) For example, those low-level use of Web 2.0 tools are the Wikis and SNS. Additionally, according to Kennedy (Kennedy et al, 2007), the well-established internet tools, such as the Learning Management System, Wikipedia and Social-Networking

Sites, are limitedly utilized by the students for learning and socializing.

\section{SNS as Supports to College/University Students' Social Life}

Beneficially, according to the studies conducted on the students in the upper Midwestern part of the USA (Greenhow \& Robelia, 2009a, b), they perceived MySpace is a useful outlet providing chances for self-expression and self-presentation in order to gain social support and maintenance. Also, by prolonging the membership in SNS such as MySpace (Greenhow, 2011), the students could be more closely to their friends due to multiple choices of communication are provided and they deemed SNS is encouraging the openness, sharing for understanding their close friends and family better and to connect to the new acquaintances of relationship in ease. And the question asked would be how the SNS and student practices could lead them into the improvement and better attainment in school learning as well as communication (Greenhow, 2011) According to finding after the review of past literature (Greenhow, 2011), she stated social networking sites generate social \& civic benefits for college students in online and offline condition. Based on this, this research proposes:

H1: There is positive relationship between the usefulness of social networking sites and the Malaysia private tertiary education's student life of social.

\section{SNS is an Aiding Tool for School Learning of College/University students}

The college students could incorporate the SNS as the social learning resources which directly and indirectly supporting the students in handling education-related tasks (Greenhow, 2011) The research question asked by Greenhow (2011) was the use of SNS by college students is involving any educational value? The factor determined that the SNS is a school tasks' helper (Greenhow \& Robelia, 2009a), is that the SNS reduces the school-related stress of students through online chatting, in example, the MySpace. The social support gained from the SNS is identified as the ecological support for students in buffering their stress (Greenhow, 2011) Based on usage of SNS, the college students are able to plan for group studies, ask school tasks' resources from the social network, sharing written works, brainstorming and exchange feedback (Greenhow, 2011) Based on the information regarding to school stress relief, this research wants to propose the hypothesis as below:

H4: Online discussion of assignments could relief school-related stress through Facebook.

The college students found SNS is useful as it also helps to develop their creativity, communication and technology skills when carrying out their school tasks with the assistance of SNS (Greenhow and Robelia, 2009b) Greenhow (2011) hypothesized the social network sites are directly $\&$ indirectly supportive in helping college students for school learning. These support the research's hypothesis as below: 
H3: There is positive relationship between the usefulness of social networking sites and the Malaysia private tertiary education's student life of learning.

\section{E. Facebook as the Popular SNS used among College/University Students}

Initially, Facebook was originally created to serve the students based on geographically-bound community where only limited to the people they could interact only if they are studying at the same higher education institution (Ellison, Steinfield \& Lampe, 2007) Also, Facebook gains successful outlook among the higher education institutions as in 2006, Facebook was the $7^{\text {th }}$ mostly-used World Wide Web and was used over 2,000 US colleges (Cassidy, 2006). Also, research emphasizes the importance of SNS in growing the social capital (Ellison et al, 2007) These social capital is important to form useful information, facilitating relationship and supporting the organizing capability (Paxton, 1999) For instance, bridging social capital is associates with the "weak ties" as the people could obtain information from their loose relationships (Putnam, 2000) Within the use of SNS, the bridging social capital would be augmented and providing the linkage of weak ties between students, continually, providing support in creating and maintaining broader network which potential to serving students as an useful resource platform (Ellison et al, 2007).

As referred to the past studies (Madge et al, 2009), many students have transferring their offline, well-known relationship to online and simultaneously, those new online relationship shifted to offline mode. Through the Facebook features of group conversations and photograph sharing, the students are able to maintain pre-existing and new relationship in affordable costs (Madge et al, 2009) Other than utilizing Facebook for social purposes, the students interact with each of other for academic-related works (Madge et al, 2009) According to the previous studies (Ellison et al, 2007), Facebook was proven useful in strengthening the weak ties between students who experiencing low self-esteem and low life satisfaction. The facts mentioned earlier are used to support the research first hypothesis and thus to propose the hypotheses below:

H2: There is positive relationship between the usefulness of social networking sites and the Malaysia private tertiary education's student's bridging social capital.

H5: Facebook could be a useful SNS platform for Malaysia private tertiary education's students in maintaining their social network and school-learning.

\section{F. Problems Arisen from Internet/SNS Usage}

Heavy usage of internet is proven disadvantaged (Jones et al, 2009) According to Anderson (2001) survey on the students from 7 US colleges and universities and another one in Ireland, the students who detected as "internet dependence" are spending higher level of time on internet (229minutes/day) compared to remaining of sample (73minutes/day) When time used for internet was not channeled properly, it is likely to result in detrimental effect such as disarrayed social and academic lives (Anderson, 2001) In the studies of Greenhow (2011), most of the popular media accounts taking the use of social media (such as
Facebook) by the students, could have result in the deficiency among the academic achievement (Hamilton, 2009; Karpinski, 2009) Furthermore, as according to Hrastinski and Aghaee (2011), the use of social media would lead into less human interaction, for instance, it would be lacking of the face-to-face interaction which leads to the issues of creative thinking, knowledge sharing and the students or their members would possibly being heavily depending on the information generated from the social media, such as Facebook and Wikipedia.The downside of using internet as well as SNS could happen if only the students use them excessively. The problems arisen by using the internet or SNS are excluded from the studies of this research.

\section{METHODOLGY}

\section{A. Measurement and Operational Definition}

The instrument the author used would assess to 4 types of measures which including sample demographic, the Facebook intensity, bridging social capital, usefulness of SNS in social-networking and school learning. Measurement scale such as ordinal and nominal scales would be used for the questionnaires' responding session designation (Saunders et al, 2007) Ordinal scale is categorical and supporting element of deciding the ranking of data such as Agree, Neutral and Disagree (Saunders et al, 2007) As the Nominal scale is too a categorical but each of the element is not able to ranked, for instance, the race (Saunders et al, 2007) Each of the measures is given operational meaning as below.

\section{B. Sample Demographic}

This measures the age, gender, race, current education level as well as the information relating to the possession of Facebook account. Only the students who experienced the use of Facebook SNS for at least a year or above, would be eligible to participate in the survey session.

\section{Usage of Facebook for Malaysian Tertiary Education Students}

In order to identify whether the Facebook would be the more preferable SNS used by the Malaysia university students, the Facebook intensity scale (Cronbach's alpha= .83) was referred and used to measure the usage of students on Facebook (Ellison et al, 2007) This measurement stresses on the two self-reported assessments of Facebook behavior and active level of the students engaged in Facebook activities, for examples, these are the number of Facebook friends owned and the length of time spent on Facebook per day (Ellison et al, 2007) This measurement includes the likert-scale questions to assess the extent of which the students connect to Facebook and the Facebook activities which integrated into their daily life (Ellison et al, 2007).

\section{Usefulness of the SNS towards Malaysian Tertiary Education's Student Life of Social}

As to identify how the SNS could support the Malaysia students in their social life such as to maintaining current and new social relationship, questionnaires designed for attempting the behavioral data

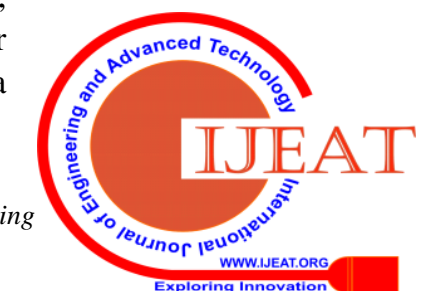


from the sampling by given the opportunity to the respondents to be responding their answer in the form of ordinal likert scale. The following questions would be assessing to the ability of SNS is providing connection to the old friends and new friends, and serving as a place for communication through the features provided by SNS, for example, Facebook (Madge, Meek, Wellens \& Hooley, 2009).Additionally, the bridging social capital of SEGi students would be surveyed in determining the relationship of the usefulness of the SNS such as Facebook and bridging social capital which refers to the maintain of social relationship (support social life) and to obtain information (support learning) from the relationship (Putnam, 2000) By using the bridging social capital subscale from William (2006), the usefulness of SNS towards the Malaysia student life of social is measureable.

\section{E. Usefulness of the SNS towards Malaysia Tertiary Education's Student Life of Learning}

In order to study the way of SNS could be helping Malaysia students in their school learning, questionnaires were designed accordingly by collecting the behavioral data based on the features of SNS such as online group discussion and online communication in order to held discussion for academic works, school stress relief and obtaining informational resources (Madge et al, 2009) The answers would be expressed in the form of ordinal likert scale which rating started from strongly disagree to strongly agree at five given level of options.

\section{DATA ANALYSIS}

\section{A. Pearson Correlation Analysis}

To interpret the relationship between the independent variable and dependent variables in this study. The Table 4.1 below presenting the result of the data collected by assessing to the variables such as the Facebook intensity scale, Usefulness of SNS towards university life of social and learning and lastly the Bridging social capital.

Table 4.1: Pearson Correlation Analysis

\begin{tabular}{|c|c|c|c|c|c|}
\hline & & $\frac{\text { Avg FBIntensit }}{y}$ & Avg Social & Avg SocialCap & Avg Learning \\
\hline \multirow{4}{*}{$\begin{array}{l}\text { Avg FBIntensit } \\
\text { y }\end{array}$} & Pearson Correlation & 1 & $.577^{+1}$ & $.437^{+*}$ & $.419^{++}$ \\
\hline & Sig. (2-tailed) & & .000 & .000 & .000 \\
\hline & $\mathrm{N}$ & 200 & 200 & 200 & 200 \\
\hline & Pearson Correlation & $.577^{* *}$ & 1 & $.560^{* *}$ & $.500^{\mathrm{m}}$ \\
\hline \multirow{3}{*}{ Avg Social } & Sig. (2-tailed) & .000 & & .000 & .000 \\
\hline & $\mathrm{N}$ & 200 & 200 & 200 & 200 \\
\hline & Pearson Correlation & $.437^{* *}$ & $.560^{\mathrm{s}}$ & 1 & $.488^{\mathrm{n}}$ \\
\hline \multirow{3}{*}{ Avg SocialCap } & Sig. (2-tailed) & .000 & .000 & & .000 \\
\hline & $\mathrm{N}$ & 200 & 200 & 200 & 200 \\
\hline & Pearson Correlation & $.419^{* *}$ & $.500^{\mathrm{m}}$ & $.488^{* *}$ & 1 \\
\hline \multirow[t]{2}{*}{ Avg Learning } & Sig. (2-tailed) & .000 & .000 & .000 & \\
\hline & $\mathrm{N}$ & 200 & 200 & 200 & 200 \\
\hline
\end{tabular}

\section{B. Correlation between the Facebook Intensity and University Social Life}

The Pearson Correlation analysis producing results which showing there is positive relationship between the Facebook intensity and university social life with R-value of .577 at a significance level of $1 \%$. The relationship of these two variables is the strongest as compared to the other variables in this research studies. Meanwhile, this indicates there is high usefulness of Facebook as choice of social networking site in supporting the Malaysia University and college students' life of social. By adopting the Facebook as the social medium, the students are able and desired to learn more about their classmates, to meet new friends and stay in touch with the current friends. Thus, the H1 hypothesis is supported in this study. This following results and findings were as well supported by the relevant past research in the western countries (Greenhow, 2011; Madge et al, 2009).

H1: There is positive relationship between the usefulness of social networking sites and the Malaysia private tertiary education's student life of social.

\section{Correlation between the Facebook Intensity and the Bridging Social Capital}

According to the table 4.1, the results show there is positive relationship between the Facebook intensity and the bridging social capital with r-value of .437 at the significance level of $1 \%$. This significant result shows the Malaysia University students are able to interact with each of others for socializing purposes and to deal with the academic-related works through the use of Facebook, for instance, to obtain the relevant education information through their current relationship. Therefore, the $\mathrm{H} 2$ and $\mathrm{H} 5$ hypotheses is supported in this study. The following results and findings also supported by the researchers in their past research (Madge et al, 2009; Ellison et al, 2007).

H2: There is positive relationship between the usefulness of social networking sites and the Malaysia private tertiary education's student's bridging social capital.

H5: Facebook could be a useful SNS platform for Malaysia private tertiary education's students in maintaining their social network and school-learning.

\section{Correlation between the Facebook Intensity and the University Learning}

By referring to the table of Pearson Correlation analysis, there is positive relationship between the Facebook intensity and the University Learning with r-value of .419 at the significant level of $1 \%$. Nonetheless, it shows the weakest relationship of these two variables as compared to the others. It could indicate that there is moderate usefulness of Facebook in learning as the Malaysia University students' main activity on Facebook would be socializing, then, learning would be coming in as second in place of activity components. By adopting the Facebook as the learning medium, the students are able to discuss academic work online, make coursework queries, reducing school stress by discussing assignments online. Thereafter, the $\mathrm{H} 3$ and $\mathrm{H} 4$ hypotheses are supported by the result of this study. This particular results and findings are supported by the studies of Greenhow and Robelia (2009).

H3: There is positive relationship between the usefulness of social networking sites and the Malaysia private tertiary education's student life of learning. 
H4: Online discussion of assignments could relief school-related stress through Facebook.

\section{E. Simple Linear Regression}

- Table 4.2: Facebook Intensity and University Social Life

The model summary below (Table 4.2 ) shows that $33.3 \%$ of the usefulness of social networking site model in social is explained by 1 independent variable as the Facebook intensity scale. The remaining $66.7 \%$ are explained by other independent variables.

Table 4.2: Model Summary

\begin{tabular}{|l|r|r|r|r|}
\hline Model & \multicolumn{1}{|c|}{$\mathrm{R}$} & R Square & \multicolumn{1}{c|}{$\begin{array}{c}\text { Adjusted R } \\
\text { Square }\end{array}$} & $\begin{array}{c}\text { Std. Error of the } \\
\text { Estimate }\end{array}$ \\
\hline 1 & $.577^{\mathrm{a}}$ & .333 & .330 & .51151 \\
\hline
\end{tabular}

a. Predictors: (Constant), Avg FBIntensity

- Table 4.3: Facebook Intensity and University Social Life (Model Summary)

The coefficients table below (Table 4.3) shows there is positive relationship between the Facebook intensity and university social life with beta value of .577 at significance level of $1 \%$. This justifies that the Malaysia university students are using Facebook to maintain their new and old friendship. Thus, the H1 hypothesis is supported by this study. Also, these results and findings are supported by the past research of similar studies (Greenhow, 2011; Madge et al, 2009).

H1: There is positive relationship between the usefulness of social networking sites and the Malaysia private tertiary education's student life of social.

Table 4.3: Facebook Intensity and University Social Life (Coefficient)

\begin{tabular}{|c|c|c|c|c|c|}
\hline \multirow[t]{2}{*}{ Model } & \multicolumn{2}{|c|}{ Unstandardized Coefficients } & \multirow{2}{*}{ 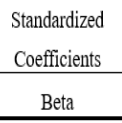 } & \multirow[t]{2}{*}{$t$} & \multirow[t]{2}{*}{ Sig. } \\
\hline & B & Std. Error & & & \\
\hline (Constant) & 2.156 & .168 & & 12.811 & .000 \\
\hline Avg FBIntensity & .467 & .047 & .577 & 9.943 & .000 \\
\hline
\end{tabular}

\section{- Table 4.4: Facebook Intensity and Bridging Social Capital}

The model summary below shows that $19.1 \%$ of bridging social capital model is explained by 1 independent variable as Facebook intensity scale. The remaining $80.9 \%$ are explained by other independent variables.

Table 4.4: Model Summary

\begin{tabular}{|l|l|r|r|r|}
\hline Model & \multicolumn{1}{|c|}{$\mathrm{R}$} & $\mathrm{R}$ Square & $\begin{array}{c}\text { Adjusted R } \\
\text { Square }\end{array}$ & $\begin{array}{c}\text { Std. Error of the } \\
\text { Estimate }\end{array}$ \\
\hline 1 & $.437^{\mathrm{a}}$ & .191 & .187 & .57067 \\
\hline
\end{tabular}

a. Predictors: (Constant), Avg FBIntensity

The coefficients table below (Table 4.5) shows there is positive relationship between the Facebook intensity and the bridging social capital with beta value of .437 at significance level of $1 \%$. This signifies that the Facebook could be a useful and preferable choice of SNS platform for Malaysia university students in supporting their learning and social activities. Thereafter, the $\mathrm{H} 2$ and $\mathrm{H} 5$ hypotheses is accepted. The results and findings also backed by the past researchers' studies (Madge et al, 2009; Ellison et al, 2007)

H2: There is positive relationship between the usefulness of social networking sites and the Malaysia private tertiary education's student's bridging social capital.

H5: Facebook could be a useful SNS platform for Malaysia private tertiary education's students in maintaining their social network and school-learning.

Table 4.5: Facebook Intensity and Bridging Social Capital (Coefficients)

\begin{tabular}{|c|c|c|c|c|c|c|}
\hline \multirow[t]{2}{*}{ Mode } & & \multicolumn{2}{|c|}{ Unstandardized Coefficients } & \multirow{2}{*}{$\begin{array}{c}\text { Standardized } \\
\text { Coefficients }\end{array}$} & \multirow[t]{2}{*}{$t$} & \multirow[t]{2}{*}{ Sig. } \\
\hline & & $\mathrm{B}$ & Std. Error & & & \\
\hline \multirow{2}{*}{1} & (Constant) & 2.205 & .188 & & 11.746 & .000 \\
\hline & Avg FBIntensity & .358 & .052 & .437 & 6.828 & .000 \\
\hline
\end{tabular}

a. Dependent Variable: Avg SocialCap

Table 4.6: Facebook Intensity and University Learning The model summary below shows that $17.6 \%$ of usefulness of social networking site model in learning is explained by 1 independent variable as Facebook intensity scale. The remaining $82.4 \%$ are explained by other independent variables.

Table 4.6: Model Summary

\begin{tabular}{|l|r|r|r|c|}
\hline Model & $\mathrm{R}$ & R Square & $\begin{array}{c}\text { Adjusted R } \\
\text { Square }\end{array}$ & $\begin{array}{c}\text { Std. Error of the } \\
\text { Estimate }\end{array}$ \\
\hline 1 & $.419^{\mathrm{a}}$ & .176 & .171 & .62789 \\
\hline
\end{tabular}

The result of coefficients shown in the table below (Table 4.7) presenting a positive relationship between the Facebook intensity and university learning which scoring beta value of .419 at significance level of $1 \%$. This proves online academic work's discussion through Facebook helped reducing the school-related stress and Facebook is useful in supporting the Malaysia university students' learning through direct query and sharing informational resources. Thus, the $\mathrm{H} 3$ and $\mathrm{H} 4$ hypotheses are accepted. Lastly, the relevant results and findings are as well proven by the studies of Greenhow and Robelia (2009).

H3: There is positive relationship between the usefulness of social networking sites and the Malaysia private tertiary education's student life of learning.

H4: Online discussion of assignments could relief school-related stress through Facebook. 
Table 4.7: Facebook Intensity and University Learning (Coefficients)

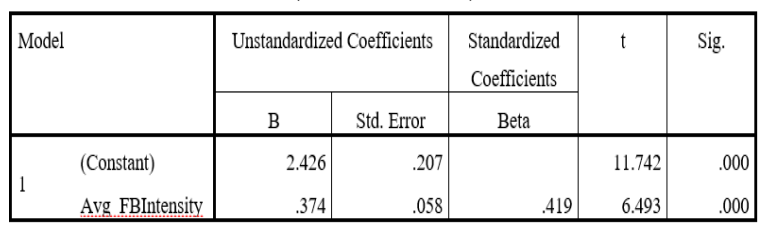

a. Dependent Variable: Avg_Learning

In a nutshell, under the studies of Simple Linear Regression, the higher the beta value the higher the significance. The Facebook intensity and the university social life is scoring the highest beta value of .577. Secondly, the Facebook intensity and bridging social capital is having beta value of .437. Lastly, the Facebook intensity and the university learning is ranked as last as it has only beta value of .417. This shows that the students would have more social activities through Facebook than the academic-related works.

\section{DISCUSSION AND CONCLUSION}

\section{A. Findings from the Descriptive Analysis}

Totally, there are 200 students from Malaysia private tertiary education located across Klang Valley, have participated in this studies in which 79 of the respondents are male $(39.5 \%)$ and 121 of the respondents are female $(60.5 \%)$ About the education level, the group of undergraduates composed as the largest pool of respondents in which there are 157 students out of the 200 respondents (78.5\%). About the usage pattern of Facebook, it is identified that there are 157 out of the 200 respondents, have been using the Facebook for 4 years or above. This shows the students have incorporated the Facebook as a SNS medium as a part of their social life support. Meanwhile, it is essential to see whether they could obtain educational support by using the Facebook (Madge et al, 2009).

Additionally, there are most respondents which are 76 out of the 200 respondents, are using Facebook for 3 hours and above everyday. Nonetheless, it is important to consider whether the students are making constructive use of Facebook in their study life such as for the purpose of academic. As for the number of Facebook friends owned, within the category of owning 801 friends or above, there are the largest group of respondents which are 70 out of the 200 respondents $(35 \%)$. This signifies the students perceived Facebook as a useful social support in their study life for maintaining their new and old relationship (Greenhow, 2011)

\section{B. Findings from the Analysis of Pearson Correlation and Simple Linear Regression}

According to the Table 4.1, the Pearson Correlation analysis shows all of relationship between the variables are significant and positive. By ranking according to the Pearson correlation value, the relationship between the Facebook intensity and university social life is positive and the most significant with the r-value of .577 at the significance level of $1 \%$. Secondly, the relationship between the Facebook intensity and bridging social capital is positive and significant with the r-value of .437 at the significance level of $1 \%$. Lastly, the relationship between the Facebook intensity and university learning is positive and least significant as compared to the other variables, with the r-value of .419 at a significance level of $1 \%$.

As according to the result of the Simple Linear Regression, there is positive and most significant relationship between the Facebook intensity and university social life with the beta value of .577 at significance level of $1 \%$. Secondly, the relationship between the Facebook intensity and the bridging social capital is positive and significant at beta value of .437 at significance level of $1 \%$. Lastly, there is positive but least significant relationship between Facebook intensity and the university learning among the variables which consists of the beta value of .419 at significance level of $1 \%$.

\section{Conclusion Based on the Analysis of Pearson Correlation and the Simple Linear Regression}

According to results of the both analysis conducted, the relationship between all the independent variable and the dependent variables are positive and significance, hence, the proposed hypotheses are accepted and summarized as the table below (Table 5.1).

Table 5.1: Results of the Hypotheses Testing

\begin{tabular}{|l|l|l}
\hline Hypotheses Proposed & Correlation & Regression \\
\hline $\begin{array}{l}\text { H1: There is positive relationship between the usefulness of } \\
\text { social networking sites and the Malaysia private tertiary } \\
\text { education's student life of social. }\end{array}$ & Accepted & Accepted \\
\hline $\begin{array}{l}\text { H2: There is positive relationship between the usefulness of } \\
\text { social networking sites and the Malaysia private tertiary } \\
\text { education's student's bridging social capital. }\end{array}$ & Accepted & Accepted \\
\hline $\begin{array}{l}\text { H3: There is positive relationship between the usefulness of } \\
\text { social networking sites and the Malaysia private tertiary } \\
\text { education's student life of learning. }\end{array}$ & Accepted & Accepted \\
\hline $\begin{array}{l}\text { H4: Online discussion of assignments could relief school- } \\
\text { related stress through Facebook. }\end{array}$ & Accepted & Accepted \\
\hline $\begin{array}{l}\text { H5: Facebook could be a useful SNS platform for Malaysia } \\
\text { private tertiary education's students in maintaining their social } \\
\text { network and school-learning }\end{array}$ & Accepted & Accepted \\
\hline
\end{tabular}

As a conclusion, the students perceived the Facebook as a useful tool and they would use it to supporting their university life in term of social and learning. Nonetheless, the students have stronger tendency of using Facebook for socializing over the learning purpose. It is mainly due to they are able to socialize with their classmates, maintain their old relationship and to meet the new people around the university (Greenhow, 2011) Meanwhile, as to improve the student experience of university life, according to this study, it is useful and would be used by the students in discussing the academic work, planning study group, request educational resources and so forth (Madge et al, 2009). 


\section{REFERENCES}

1. Anderson, K.J. (2001). Internet use among college students: an exploratory study. Journal of American College Health, 50(1), 21-26.

2. Barnes, S.B. (2006), "A privacy paradox: social networking in the United States", First Monday, 11(9), (accessed: 05/11/2010) Retrieved from http://firstmonday.org/issues/issue11_9/barnes

3. ComScore. (2009). Online usage in Malaysia. comScore, Inc Retrieved from :www.comscore com/Press_Events/Press_Release/2009/8/Maybank_Leads_as_the Most_Visited_Local_Site_in_Malaysia

4. Cormode, G. and Krishnamurthy, B. (2008), "Key differences between Web 1.0 and Web 2.0", First Monday, 13(6), (accessed: 05/10/2008), Retrieved from ww.uic. edu/htbin/cgiwrap/bin/ojs/index.php /fm/article/view/2125/1972

5. Cotten, S.R., \& Jelenewicz, S.M. (2006). A disappearing digital divide among college students?. Social Sciences Computer Review, 24(4), 497-506.

6. Ellison, N. B., Steinfield, C., \& Lampe, C. (2007). The Benefits of Facebook "Friends:" Social Capital and College Students' Use of Online Social Network Sites. Journal of Computer-Mediated Communication, doi: 10.1111/j.1083-6101.2007.00367

7. Greenhow, C. (2011). Online social networks and learning. On the Horizon, 19(1), 4-12. doi: 10.1108/10748121111107663

8. Greenhow, C., \& Robelia, B. (2009). Old Communication, New Literacies: Social Network Sites as Social Learning Resources. Journal of Computer-Mediated Communication, 14, 1130-1161. doi 10.1111/j.1083-6101.2009.01484.x

9. Greenhow, C., \& Robelia, E. (2009b). Informal learning and identity formation in online social networking. Learning, Media and Technology, 34(2), 246-59.

10. Greenhow, C., Robelia, B., \& Hughes JE. (2009). Learning, Teaching, and Scholarship in a Digital Age, Web 2.0 and Classroom Research: What Path Should We Take Now? Educational Researcher, 38(4), 246-259. doi: 10.3102/0013189X09336671

11. Hamilton, A (2009) What Facebook users share: lower grades. Time Magazine, April 14. Retrieved from www.time.com/time /business/article/0,8599,1891111,00.html

12. Hrastinski, S., \& Aghaee, N.M. (20111) How are campus students using social media to support their studies? An explorative interview study. Educ Inf Technol. Doi: 10.1007/s10639-011-9169-5

13. Jones, S., Johnson-Yale, C., Millermaier, S., \& Seoane Perez, Francisco. (2009). Everyday life, online: U.S. college students' use of the Internet. First Monday. 14(10). Retrieved from http:// firstmonday.org/htbin/cgiwrap/bin/ojs/index.php/fm/article/view/26 49/2301

14. Karpinski, A. C., \& Scullin, M. H. (2009). Suggestibility under pressure: Theory of mind, executive function, and suggestibility in preschoolers. Journal of Applied Developmental Psychology, 30(6), 749-763.

15. Kennedy, G., Dalgarno, B., Gray, K., Judd, T., Waycott, J., Bennett, S., Maton, K., Krause, K.L., Bishop, A. \& Chang, R. (2007). The net generation are not big users of Web 2.0 technologies: Preliminary findings. Proceedings ASCILITE Singapore 2007, 517-25.

16. Kvavik, R.B., \& Caruso, J.B. (2005). Students and information technology, 2005: Convenience, connection, control and learning. Educause Center for Applied Research. Retrieved from http://net.educause.edu/ir/library/pdf/ERS0506/ekf0506.pdf

17. Madge, C., Meek, J., Wellens, J., \& Hooley, T. (2009). Facebook, social integration and informal learning at university: 'It's more for socializing and talking to friends about work than for actually doing work'. Learning, Media and Technology, 34(2), 141-155. doi: $10.1080 / 17439880902923606$

18. Mansson, D. H., \& Myers, S. A. (2011). An initial examination of college students' expressions of affection through Facebook. Southern Communication Journal, 76(2), 155-168.

19. Mohd Hafiz Zakaria, Watson, J., \& Edwards, Sylvia L. (2010). Investigating the use of Web 2.0 technology by Malaysian students. Multicultural Education \& Technology Journal, (4)1, 17-29. doi: 10.1108/17504971011034700

20. Paxton, P. (1999). Is social capital declining in the United States? A multiple indicator assessment. American Journal of sociology, 105(1), 88-127
21. Putnam, R. D. (2000). Bowling Alone. New York: Simon \& Schuster

22. Saunders, M., Lewis, P., \& Thornhill, A. (2007) Research Methods for Business Students. ( $4^{\text {th }}$ edition). Milan, Italy: Pearson Education Limited

23. Saunders, M., Lewis, P., \& Thornhill, A. (2009). Research Methods for Business Students. ( $5^{\text {th }}$ edition). Milan, Italy: Pearson Education Limited. Retrieved from http://books.google. com.my/books?id=u-txtfaCFiEC \&dq=saunders +research+methods+for+business+students\&hl=en\&ei=bnm3TpzC NIn4rQev1PXGAw\&sa=X\&oi=book_result\&ct=result\&resnum $=1 \&$ ved=0CDYQ6AEwAA

24. William, D. (2006). On and off the "net: Scales for social capital in an online era. Journal of Computer-Mediated Communications, 11(2) article 11. Retrieved from: http://jcmc.indiana edu/vol11/issue2/williams.htm

25. Wilson, R.A. (1999). Revelry, revelation, or research: What are college students really doing on the internet. Paper presented at ACRL's Ninth National Conference: Racing toward tomorrow. Retrieved from :http://ala.org/ala/mgrps/divs/acrl /events/pdf/wilsonr99.pdf

\section{AUTHORS PROFILE}

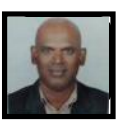

Mr. Ilangovan Perumal is a Senior Lecturer Faculty of Business, Accounting and Management, Segi University, Kota Damansara. His expertise is in the areas of management information systems, ecommerce, computer science educational systems and IT in business. He has taught various computer related subjects for various background of students, locally and internationally ranging from certificate to undergraduate level. He has published few papers in the various computer and business related journals. Mr. Ilangovan Perumal holds a Master degree in Computer Science from University of Malaya and currently pursuing Phd in IT.

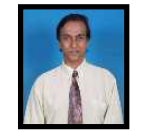

Associate Professor Dr. Azween Abdullah has been contributing to research, teaching, consulting and in administrative services to the institutions that he has been working for thus far. He is a professional development alumni of Stanford University and MIT and his work experience includes thirty years as an academic in institutions of higher learning and as director of research and academic affairs at two institutions of higher learning, vice-president for educational consultancy services, fifteen years in commercial companies as Software Engineer, Systems Analyst and as a computer software developer and IT/MIS consultancy and training. Dr. Azween Abdullah has several patents under his name and been actively serving as expert reviewer and editorial board member for several high impact technical journals. Prior to joining Taylors University, Dr. Azween Abdullah served as faculty member at Monash University, Malaysia and Petronas University of Technology. He served as an adjunct research professor at the Malaysian University of Science and Technology and currently serves as the adjunct professor at SEGi University. He has guided and produced more than twenty post-graduate students. He is a fellow of the British Computer Society and senior member of IEEE. Dr. Azween Abdullah's general research interests are in the areas of cyber security and trustworthy computing, formal models of computation, and graph analytics in cyber security. $\mathrm{He}$ has been consulting for some technology companies in content development and has done research on emerging areas of networked and quantum security. He has been involved with a number of government and semi-government organizations in Malaysia in the role of external consultant and currently works with several government linked companies and industries to promote cyber security capacity development. He has also published more than 150 publications in various technical journals and conference proceedings and has given technical talks in a number of key international conferences, industry summits and forums.

Dr. Muthaloo Subramaniam is currently a Senior Lecturer at the Faculty of Business, Accounting and Management (FOBAM) at SEGi University, Malaysia for more than 8 years Numerous positions were held during and before joining SEGi Among others, he was a Deputy Head of FOBAM, Faculty Manager for Academic (Dean) of Faculty of Business Management and Globalisation, Limkokwing University of Creative Technology as well Student Advisor of Partner Programmes of Anglia

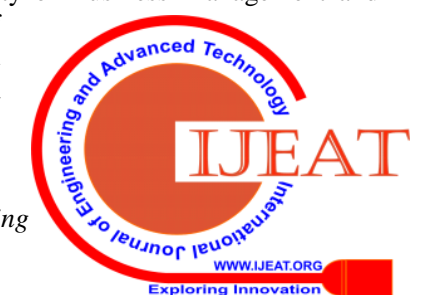


Ruskin University and Head of Accounting Programmes Department at YPC International College (Kolej Teknologi YPC iT-Web). He holds a PhD in Management from SEGi University, Master degree in Management Majoring IT from University Putra Malaysia and Bachelor's degree in Accounting (Hons) from University of Malaya. He is a well experienced accounting, IT and business professional with over 19 years of experience in the corporate and higher education. He possess experience in corporate setting on IT and accounting jobs before fully involved in teaching both local and international programmes and research. As to date, he has published several papers in peer reviewed journals. His versatility prevails at all time. In a professional attachment, he is an Associate Member of Malaysian Institute of Accountants, Associate Member of Chartered Tax Institute of Malaysia, Member of Malaysian Institute of Management and Life Member of Malaysian Human Resource Management.

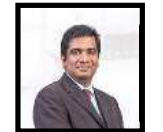

Dr. Mahadevan Supramaniam serves as Director, Research and Innovation Management Centre \& Institute of Graduate Studies of SEGi University. His expertise lies in Research and Development Policies, Enterprise Resource Planning, Computer Science \& security system, Business Process Management and Integrated Technologies for industries. He has shared most of his experiences on his expertise area through public talks and has written many papers and books which has been published all over the world. Dr Mahadevan holds a DBA from the Twintech International University College of Technology Malaysia and a Master's of Software Engineering degree from University of Malaya.

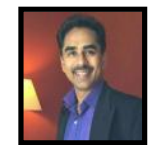

Dr. Sugumaran Selladurai currently serves as a Dean, Faculty of Business, Accounting \& Management, SEGi University. Dr. Sugumaran attained his Doctorate in Business Administration from University Utara Malaysia and Master in Business Administration major in Marketing Management from University of Wales, U.K and Bachelor of Accountancy from University of Bolton, U.K. He has more than 23 years of experience in the education industry, which includes regulatory, product development, operation and management. He plays a pivotal role in transforming the largest Faculty of Business, Accounting and Management into the most profitable unit in SEGi University. Apart from his leadership role at the faculty, he is also involved in research and development, focusing in the fields of Strategic Planning, Corporate Social Reporting and Active Teaching and Learning. He has published number of articles including SCOPUS indexed journals. 